76 巻 765 号 $(2010-5)$

\title{
植物系バイオ燃料によるディーゼル機関の性能 ならびに排気特性に関する研究*
}

\author{
坂田知 浩*1, 北川浩 史*2 \\ 登坂 茂*2, 藤 原 康 博*2
}

\section{The Performance of the Diesel Engine by the Biomass Fuel and a Study about the Exhaust Characteristic}

\author{
Tomohiro SAKATA*3, Hiroshi KITAGAWA, \\ Shigeru TOSAKA and Yasuhiro FUJIWARA
}

\footnotetext{
${ }^{* 3}$ Department of Automotive Engineering, Hokkaido Automotive Engineering College, 2-6-2-1 Nakanoshima, Toyohira-ku, Sapporo-shi, Hokkaido, 062-0922 Japan
}

\begin{abstract}
Although some countries use esterificated fuel, which is made out of useless vegetable oil, it makes troubles which are emission of white and black smoke, becoming worse of engine start, and so on. Since biofuels are oxygenated fuels, there are concerns abous production of large amounts of aldehydes, which are oxygenated toxic substances. This paper examines the cause of precipitation of solids in fuel at low temperatures, looks at trends in production of aldehydes from biofuels, compares exhaust characteristics when using 3 types of biofuel and gas oil in a diesel engine, and clarifies what effect constituent fatty acids have on exhaust characteristics. As the percentage of saturated fatty acids increases, the cloud point and freezing point rise, and a certain degree of correlation is evident between the cloud point and freezing point. With methyl oleate, production of aldehydes begins to increase around 400 , and the produced amount is small in the low temperature range. With methyl ester fuels, there is an increase in $\mathrm{NO}_{x}$, and a decrease in THC, CO and exhaust smoke density, compared to gas oil.
\end{abstract}

Key Words : Diesel Engine, Liquid Fuel, Vegetable Oil, Alternative Fuel, Combustion Products, Combustion Phenomena, Fuel Properties

\section{1. まえがき}

現在，石油資源の枯混と， $\mathrm{CO}_{2}$ による地球温暖化が 大きな社会問題となっている．植物油を原料として生 成されるバイオ系燃料は非枯渴系燃料であると共に， 植物の成長過程で大気中の $\mathrm{CO}_{2}$ を固定化するために， 生涯的な $\mathrm{CO}_{2}$ 排出量を抑制するのに効果的であると考 えられることから，石油系燃料の代替燃料として注目 されている.

これまでに，バイオ系燃料には廃食用油から製造さ れたエステル化燃料が実用化されているが，冬期間に 黒煙や白煙の発生，ならびにエンジン始動性の悪化な どのトラブル発生が起きている。これらは然料中に析 出した固形物が，インジェタションポンプ内のプラン

* 原稿受付 2009 年 8 月 7 日.

*1 正員, 北海道白動車短期大学自動車工業科 (昰 062-0922 札 幌市豊平区中の島 2 条 6-2-1)

*2 正員, 北海道工業大学機械システム工学科(画006-8585 柇 幌市手稲区前田 7 条 15-4-1)

E-mail : sakata@haec.ac.jp
ジャー等に固着したことが原因であると推測されてい $ろ^{(1)}$.

また，バイ才系燃料は含酸素燃料であることから， 含酸素系有害成分であるアルデヒド類が多く生成され ることが䊢念される。

本研究においては，低温時に燃料中に固形物が析出 寸る原因の検討，バイ才系燃料からのアルデヒド類の 生成傾向，ならびに 3 種類のバイ才系燃料と軽油（Gas oi1）をディ一ゼル機関に用いた場合の排気特性を比 較し, 構成脂肪酸が排気特性によ゙のような影響を与え るかを明らかにすることを目的に検討を行った。

\section{2. 実縸装䍗及び方法}

各脂肪酸メチルからのアルデヒド類の生成傾向を 調べるために，熱分解装置の試作を行った，図 1 に熱 分解装置の概要を示す. 加熱炬に洼外線ゴールドイ メ一ジ㸝を用い, 加熱雲囲気，加熱時間を任意に設定 することで，燃料性状にかかわらず同一条件で加熱す ることが可能である。なお，熱分解条件は，投入試料 量を $0.5 \mu \mathrm{L}$, 窒素, 酸素混合雲囲気で行い, 加熱時 間 40 秒 一定とし, 加熱温度を $300^{\circ} \mathrm{C}$ 加 $800^{\circ} \mathrm{C}$ 
範囲で変化させた際のアルデヒド類の分析・測定を行 った。なお，発生したアルデヒド類はDNPH法を用いて ECD付ガスクロマトグラフ（島津製作所 $\mathrm{GC}-14 \mathrm{~B}$ ) で 測定した. 分析条件を表 1 に示す。

植物油を用いたメチルエステル燃料の性状分析に はFID付ガスクロマトグラフ (島津製作所GC-14B)で 測定を行った. 分析条件を表2に示す.

本赛験に使用した機関は，定格出力は $7.7 \mathrm{~kW} / 2600$ $\mathrm{rpm}$ 水冷単気筒横型 4 サイクル直接噴射式ディーゼ ル機関であり, 実験は最大トルク発生付近の $1600 \mathrm{rmm}$, 燃費最良付近の噴射時期で負荷を種々に変化させて 行った. NOx化学発光式分析計（島津製作所NOA-70 00）を用いた, Total hydrocarbons (THC) はFID付ガス クロマトグラフ（島津製作所GC-9A），無機ガスはTC D付ガスクロマトグラフ（島津製作所GC-9A）を用いて 分析を行った。また，排気黒煙濃度 (Smoke) はボッシ ニ式スモークメータを使用した。

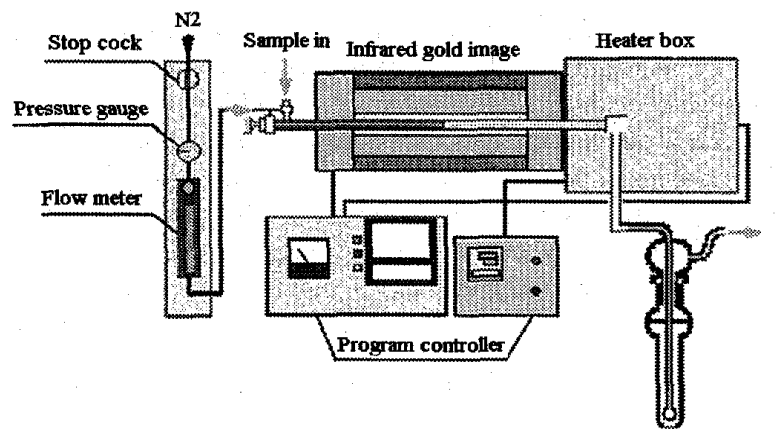

Fig. 1 Schematic diagram of experimental apparatus

Table 1 Analysis conditions of aldehyde components

\begin{tabular}{|l|c|}
\hline Main Column & $\mathrm{DB}-1$ \\
& $(0.25 \mathrm{~mm}$ I.D. $\times 30 \mathrm{~m} \mathrm{df}=0.25 \mu \mathrm{m})$ \\
\hline Initial Temp. & $80^{\circ} \mathrm{C}$ \\
Initial Time & $1 \mathrm{~min}$ \\
Prog Rate 1 & $20^{\circ} \mathrm{C} / \mathrm{min}$ \\
Final 1 Temp. & $180^{\circ} \mathrm{C}$ \\
Final 1 Time & $15 \mathrm{~min}$ \\
Prog Rate 2 & $2^{\circ} \mathrm{C} / \mathrm{min}$ \\
Final 2 Temp. & $208^{\circ} \mathrm{C}$ \\
Final 2 Time & $0 \mathrm{~min}$ \\
Prog Rate 3 & $5^{\circ} \mathrm{C} / \mathrm{min}$ \\
Final 3 Temp. & $240^{\circ} \mathrm{C}$ \\
Final 3 Time & $35 \mathrm{~min}$ \\
inj. Temp. & $250^{\circ} \mathrm{C}$ \\
Det & $\mathrm{C}-\mathrm{ECD}$ \\
Det Temp. & $280^{\circ} \mathrm{C}$ \\
Carrier Gas & $2.3 \mathrm{ml} / \mathrm{min}$ \\
Split Ratio & 50 \\
\hline
\end{tabular}

実験に用いたバイオ燃料は菜種（Rapeseed oil）， 大豆 (Soybean oil), パーム油 (Palm oil) のメチ ルエステルを用い，比較のために軽油を用いた．熱分 解実験においては，供試燃料に含まれる主たる構成脂 肪酸であるパルミチン酸, オレイン酸, リノレン酸を 使用した。

エステル化燃料の曇り点はJIS K 2269により測定 を行った．また，動粘度はウベローデ動粘度計を用い， 測定はJIS K 2283 により測定を行った。

\section{3. 実験䊅果及び考察}

3.1 植物油メチルエステルの分析廃食用油 を用いた場合に起きたトラブルの原因として考えら れる㜣料中の固形物の析出は，燃料の構成成分による ものだと考えられる，そこで，廃食油の成分分析を行 った. 図 2 は廃食油エステル化燃料の分析結果を示し

Table 2 Analysis conditions of methyl ester fuels

\begin{tabular}{|l|c|}
\hline Main Column & $\mathrm{CP}-\mathrm{Sil}-88$ \\
& $(\phi 0.25 \mathrm{~mm} \times 50 \mathrm{~m} \mathrm{df}=0.20 \mu \mathrm{m})$ \\
Initial Temp. & $100^{\circ} \mathrm{C}$ \\
Initial Time & $0 \mathrm{~min}$ \\
Prog Rate & $10^{\circ} \mathrm{C} / \mathrm{min}$ \\
Final Temp. & $190^{\circ} \mathrm{C}$ \\
Final Time & $500 \mathrm{~min}$ \\
Inj. Temp. & $270^{\circ} \mathrm{C}$ \\
Detecter & $\mathrm{FID}$ \\
Det Temp. & $300^{\circ} \mathrm{C}$ \\
Carrier Gas & $0.33 \mathrm{ml} / \mathrm{min}$ \\
Sample Size & $0.5 \mu 1$ \\
Split Retio & 108 \\
\hline
\end{tabular}

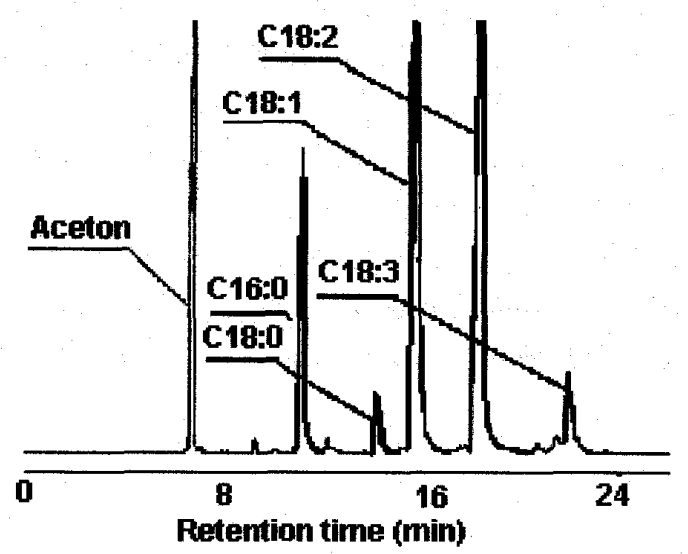

Fig. 2 Example of analyzing methyl ester fuel using waste edible oil 
たものである.なお，分析に際しては，アセトンを溶媒に 用いて 8 倍に希釈して行った。

図に示すように，最初に溶出しているピークは溶媒 に使用したアセトンであり，10.9minにパルチミン酸 メチル (C16:0)，13.8minkステアリン酸メチル $(\mathrm{C} 1$ 8:0)，16.0minkオレイン酸メチル(C18:1)，17.7min にリノール酸メチル (C18:2)，21.4minにリノレン酸 メチル (C18:3) が検出されている．植物油のエステ ル化燃料は, 主にこれらの5成分で構成されている(2). 主な構成成分中には飽和脂肪酸が含まれており，一般 的に飽和脂肪酸は融点が高く常温では固体である場 合が多い.エステル化燃料中に含まれる飽和成分であ るステアリン酸メチルとパルミチン酸メチルの融点

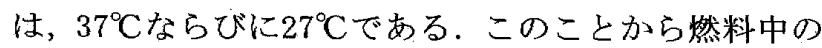
固形物の析出は, 飽和脂肪酸が影響していると推测さ れる。

図3に脂肪酸の割合を示す。図に示すように，今回 用いた廃食用油中の飽和成分は $15.2 \%$ となり，不飽和 脂肪酸は $82.7 \%$ を占めている. 実用化されている廃

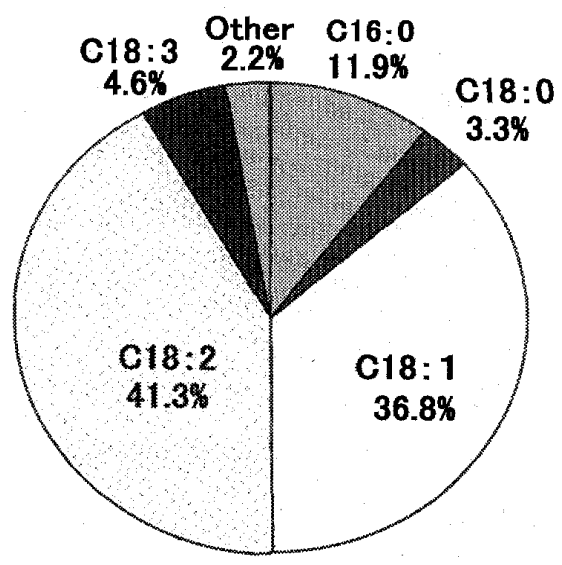

Fig.3 Example of analyzing methyl ester fuel using waste edible oil

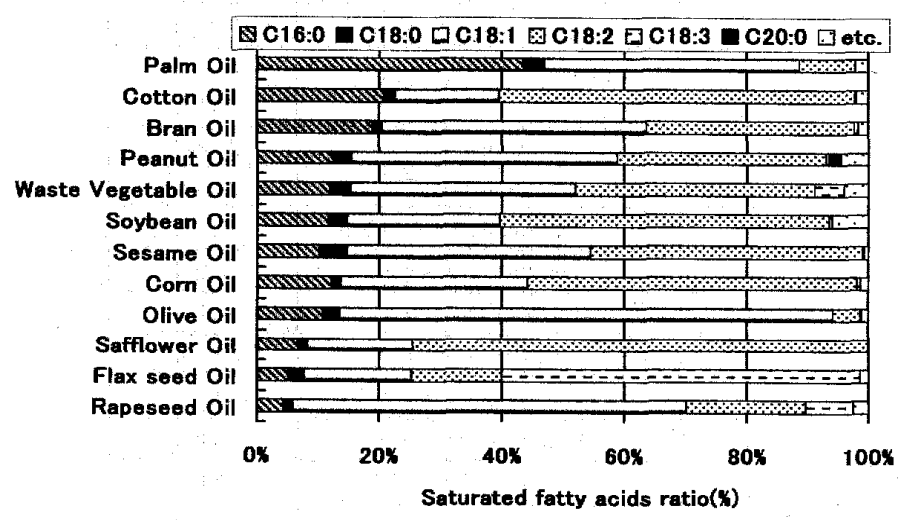

Fig. 4 Constituents of each vegetable oil
食用油のエステル化燃料の量り点はー $3^{\circ} \mathrm{C} \sim 4{ }^{\circ} \mathrm{C}$ と報 告されている(3)。乙かし，東京の1月の最低平均気

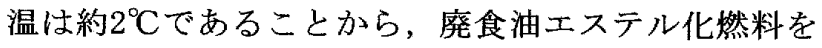
用いた際のトラブルの原因としては, 飽和脂肪酸が比 較的多く含まれており, 燃料が外気温によって薷り点 以下まで泠却され, 飽和脂肪酸メチルが固形脂として 析出したと推測される.

3. 2 的和脂肪酸含有割合と量り点 前述の結 果から，飽和脂肪酸の含有割合が曇り点に影響してい ると考えられることから，各植物油における飽和脂肪 酸の含有割合が，量り点に及ぼす影響を調べるために 11 種類の植物油の分析を行い, 各植物油の脂肪酸構成 割合を調心たた。

図4は各植物油をメチルエステル化した然料の脂肪 酸構成の割合を示した。図に示すように，植物油によ り脂肪酸構成は異なり, 菜種油メチルエステルの飽和 脂肪酸割合は $6.2 \%$ と最も少なく，パーム油メチルエ ステルの飽和脂肪酸割合は $46.8 \%$ とエステル化燃料 中で最も多い值であることが分かる。

この分析結果を元に飽和脂肪酸と䍛り点の相関の 検討を行う事とした。しかし，燃料が外気温によって 曇り点以下に泠却され固形脂が析出した場合, 実際に ディーゼル機関を始動するときに，曇り点以上の温度 まで燃料温度が上昇していたとしても析出点以下の 場合には，固形脂が残留していてトラブルを発生させ る危険性がある.したがって, 析出点の測定も併せて 行った。図5は, 飽和脂肪酸の割合と曇り点, 析出点 の関係を比較して示したものである.

図から飽和脂肪酸の割合が増加すると曇り点, 析出 点ともに上昇しており，曇り点と析出点の間には一定 の相関が見られることがわかる. 落花生油メチルエス テルとゴマ油メチルエステルを除いた析出点は曇り

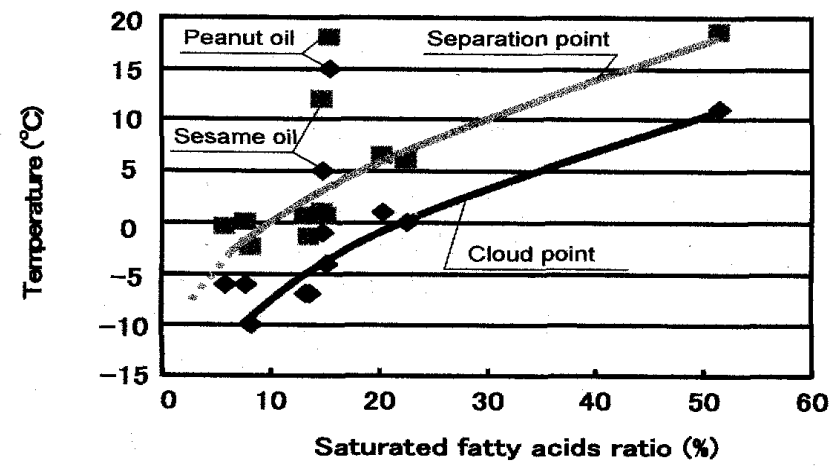

Fig. 5 Variation in cloud point and freezing point due to change in percentage of saturated fatty acids 
点とほぼ同様の傾向を示し，5〜 $6^{\circ} \mathrm{C}$ 程度の差がみられ た. 落花生油メチルエステルとゴマ油メチルエステル の薷り点，析出点は共に高いがこれは，落花生油メチ ルエステルは融点が $65^{\circ} \mathrm{C}$ と高いC $20: 0$ あるアラキ ジン酸メチルを約 $2 \%$ 含んでいることから上昇したも のと考えられる。また，ゴマ油メチルエステルはステ アリン酸メチルが $4.7 \%$ と比較的多く含んでいること によるものと考えられる．さらに，飽和脂肪酸含有割 合と析出点の相関から，析出点がー $10^{\circ} \mathrm{C}$ とる飽和脂 肪酸含有割合を推测すると約 $2 \%$ となることが分かる.

\section{3 メチルエステル涺合燃料の低温時における}

性状 前述の結果から, 最も飽和脂肪酸の少ない菜 種油メチルエステルであれば東京近郊での冬期間に おける使用も可能と言えるが, 寒冷地では冬期間の使 用は困難であると考えられる。したがって，寒冷地で 使用する場合には量り点，ならびに動粘度の低い石油 系燃料と混合して用いる必要があると言える.

寒冷地での使用を考えた場合, 構成脂肪酸中の飽和

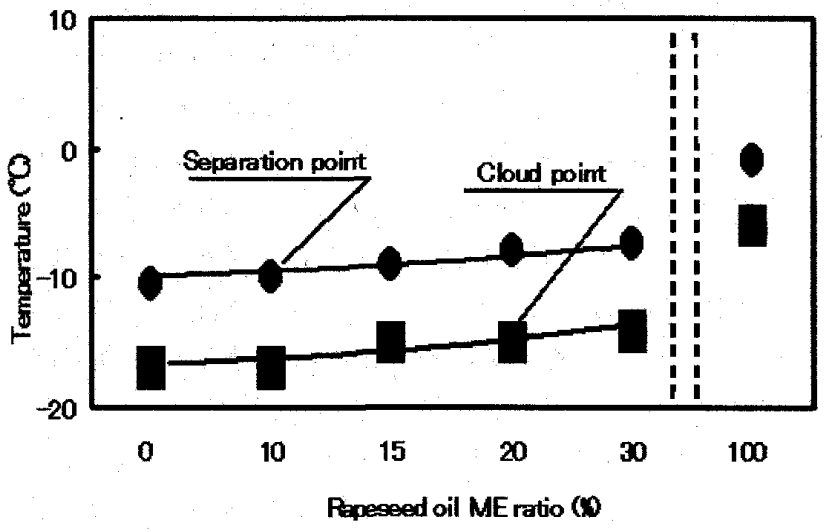

Fig.6 Variation in cloud point and freezing point due to blending percentage of rapeseed oil methyl ester fuel

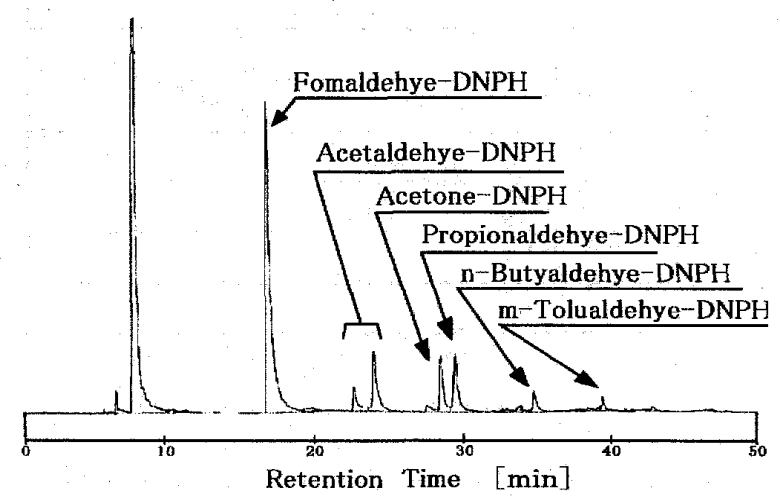

Fig. 7 Aldehyde analysis
脂肪酸が低い植物油を用いることで, 石油系燃料への 混合割合を増加させることが可能である，そこで，国 内で生産可能であり，飽和脂肪酸含有割合が低い菜種

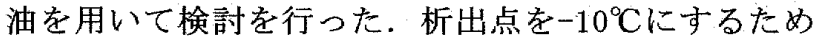
には，混合燃料中の飽和脂肪酸含有割合を質量割合で

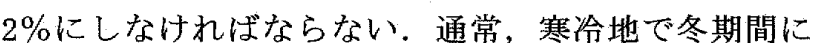
使用される特 3 号軽油に菜種油メチルエステルを混合

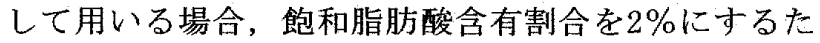
めには $30 \%$ まで混合することが可能であると考えら れる。

図6は，特3号軽油に対する菜種油メチルエステルの 混合割合と曇り点, 析出点の関係を示したものである。 図から, 菜種油メチルエステルの混合割合を増加させ ると量り点, 析出点のいずれもやや上昇することが分 かる. $30 \%$ 混合燃料の場合，飽和脂肪酸の割合は1.9\%

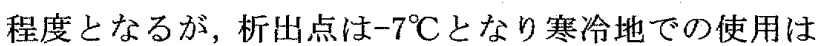
困難である。しかし，15\%混合燃料の場合には飽和脂 肪酸の割合が $0.93 \%$ 程度となり, 析出点が $-9.5^{\circ} \mathrm{C}$ と なることから寒泠地での使用が可能であると考えら 机る。

\section{4 脂肪酸メチルによるアルデヒドの生成㑯向}

メチルエステル燃料と軽油のアルデヒド類の生成 傾向について調べるに際し, 脂肪酸メチルの中でも比 較的多く含まれているオレイン酸メチルの熱分解を 行い,アルデヒド類の分析を行った。また本実験は定 性試料を用いて判明している13成分をアルデヒド類 とした，定性を行ったアルデヒド成分を表3に示す。 図7に分析結果の一例亡して，オレイン酸メチルを50 $0{ }^{\circ} \mathrm{C}$ で加熱した際のクロマトグラムを示す. 図に示す ように，8分付近に大きなピークが溶出しているが，

Table 3 Analyzed aldehyde ingredient

\begin{tabular}{|c|c|c|}
\hline & Compound & R.Time (min) \\
\hline 1 & Formaldehyhde-DNPH & 16.575 \\
\hline 2 & Acetaldehyde-DNPH & 22.771 \\
\hline 3 & Acotone-DNPH & 24.092 \\
\hline 4 & Acrolein-DNPH & 28.681 \\
\hline 5 & Propionaldehyde-DNPH & 29.174 \\
\hline 6 & Grotonaldehyde-DNPH & 32.900 \\
\hline 7 & 2 -Butanone-DNPH & 33.764 \\
\hline 8 & Methacrolein-DNPH & 34.143 \\
\hline 9 & n-Butyaldehyde-DNPH & 34.677 \\
\hline 10 & Benzaldehyde-DNPH & 35.872 \\
\hline 11 & Valeraldehyde-DNPH & 37.821 \\
\hline 12 & m-Tolualdehyde-DNPH & 39.195 \\
\hline 13 & Hexaldehyde-DNPH & 42.504 \\
\hline
\end{tabular}


これは末反応のDNPHである。これ以外では，ホルムア ルデヒドの生成量が最も多く，アセトアルデヒド, プ ロピオンアルデヒドの順となっている.アセトアルデ ヒドのピークは二つ存在するが,これはDNPHと反応し た際に生成される異性体である，ケトン類のアセトン を除くとブチルアルデヒドも比較的多く生成されて いる.

図8は，供試植物油メチルエステル燃料に比較的多 く含まれている, 飽和脂肪酸メチルであるパルミチン酸 メチル，不飽和脂肪酸メチルであるオレイン酸メチル， ならびにリノール酸メチルから生成されるアルデヒ ド類の生成傾向について比較して示したものである. また，トータルアルデヒドとは定性試料を用いて判明 している13成分のピークエリアを合計したものであ る.図から、パルミチン酸メチルは, 不飽和脂肪酸メチ ルに比べ，広い温度範囲でアルデヒド類が生成されて おり, $400^{\circ} \mathrm{C}$ 付近では3成分中最も多く生成されている. このことから，低い温度域ではパルミチン酸メチルが

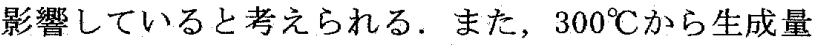
が増加し始め $500^{\circ} \mathrm{C} て ゙$ 值が最大となり，以降温度の上 昇と共に減少している，不飽和脂肪酸メチルでは40 $0^{\circ} \mathrm{C}$ 方生成量が増加し始め, $600^{\circ} \mathrm{C} て ゙$ 值が最大となり, 以降減少している，不飽和脂肪酸メチルで比較すると

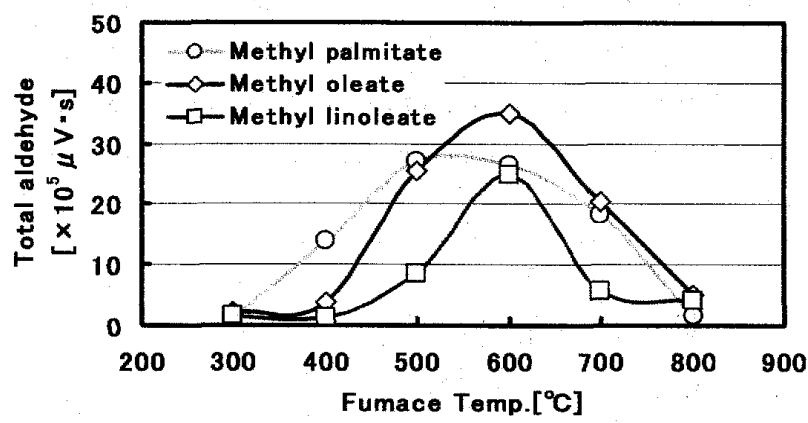

Fig.8 Total aldehyde emissions due to each methyl ester

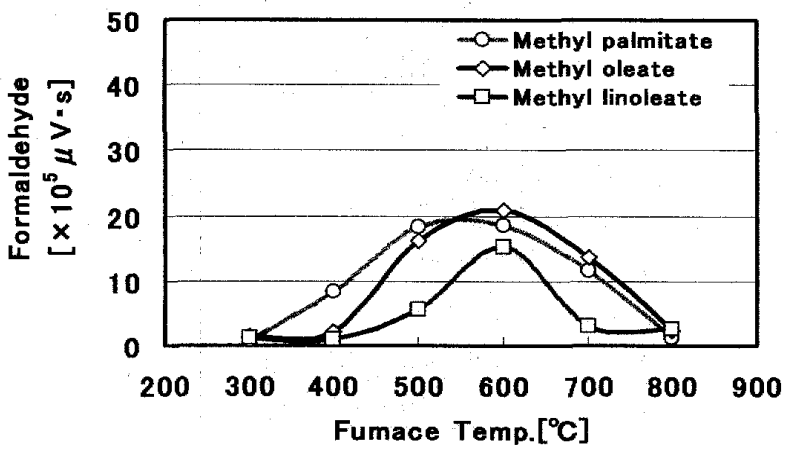

Fig.9 Formaldehyde production trends of fatty acid methyl
生成量の増加する $500^{\circ} \mathrm{C} \sim 700^{\circ} \mathrm{C}$ において, オレイン酸 メチルからの排出量が多い事から，オレイン酸メチル はアルデヒド類の排出に影響があると考えられる.

図9は，前述の結果から，ホルムアルデヒドの生成量 を比較して示したものである. 図からホルムアルデヒ ドは, トータルアルデヒドの大部分を占めており，生 成傾向はいずれもトータルアルデヒドと同様よなっ ている。

\section{5 負荷を変化させた場合の譏関性能および} 排気特性、各メチルエスデル燃料の構成脂肪酸割 合には差異があるため, 負荷を変化させた場合に各メ チルエステル燃料の機関性能, および排気特性にどの ような影響を及ぼすのか検討を行った。

機関性能はどの負荷領域においても大きな差異は 認められず, 軽油を用いた場合と同等の性能が得られ ると言える.図10に菜種油メチルエステル(RME 0i1), 大豆油メチルエステル (SME 0i1)，ならびにパーム 油メチルエステル（PME Oil）を用いた場合の排気特 性を示す。また，比較のために軽油の結果も併せて示 す. 図から各メチルエステル燃料を用いた場合の負荷 に対するN0xの排出傾向は同様であるが，各メチルエ ステル燃料を用いた場合の濃度は, すべての負荷範囲 において軽油より高い值を示している。，一方， THCの 排出傾向はいずれの燃料も同様に, 高負荷域になると 増加しているが，排出濃度はいずれのメチルエステル も軽油より大幅に減少していることが分かる.

COは低負荷で軽油，メチルエステル燃料ともに差は ないが, 中負荷以降では, 軽油より低いことがわかる. さらに排気黑煙濃度も広い負荷範囲で軽油よりも低 いことがわかる.いずれのメチルエステル燃料も軽油 より未燃成分が減少しているのは，メチルエステル燃 料は然料成分中に酸素分子を含むことから，燃料と等 気の混合拡散が不十分な領域においても燃料に含ま れている酸素により燃焼が改善されたことによるも のと考えられる.また，その結果NOxが増加したもの と考えられる. 次に 3 種類のメチルエステル燃料で比 較すると，NOxはパーム油メチルエステル，大豆油メ チルエステル, 菜種油メチルエステルの順に濃度が高 くなっている. THCは，菜種油メチルエステル，大豆 油メチルエステル, パーム油メチルエステルの順に高 くなっている。一方，不完全燃焼生成物のTHC, $\mathrm{CO}$, ならびに排気黑煙濃度は，いずれのメチルエステルも 傾向は同様で，差異も小さいが，菜種油メチルエステ ル，大豆油メチルエステル，パーム油メチルエステル の順に高くなる傾向が認められる。すなわち，不飽和 
脂肪酸の割合が多い燃料ほど減少する傾向があるこ そが分かる.これは，不飽和脂肪酸の割合が多いメチ ルエステル燃料ほど, 動粘度, 曇り点, 析出点が低く なっている. 動粘度が低下したことによって噴霧され たメチルエステル燃料の液滴が小さくなり，噴霧が改 善され空気との混合拡散が良好となることが，燃焼の 改善に慗がり，不完全燃焼生成物が減少した主要因と 考えられる.すなわち構成脂肪酸の割合は，排気特性 に影響を及ぼすものと言える。

図11は，3種類のメチルエステル燃料を用いて負荷 を変化させた際のアルデヒド排出量を比較して示し たものである、比較のために軽油の結果も合わせて示 す. 図からトータルアルデヒドの排出傾向は, 燃料に よって幾分異なるが，概槓荷が高くなると減少する 傾向が認められる。また，オレイン酸メチルを最も多 く含む菜種油メチルエステルが 3 種類のメチルエステ ル燃料では，アルデヒド排出量が最も多く排出されて いることから，前述の通りオレイン酸メチルが影響し ていると考えられる。しかし，その排出濃度はPPM才 一ダーの微量なものであり，負荷によって軽油からの 排出量が多い場合もある.

\section{4. 䊅}

以上の結果を要約すると以下の通りである.

（1）飽和脂肪酸の割合が増加すると, 量り点, 析出点 ともに上昇しており，曇り点と析出点の間には一 定の相関が見られる。

（2）特3号軽油に菜種油メチルエステルを $15 \%$ 混合し たものであれば，飽和脂肪酸の割合が $0.93 \%$ 程度

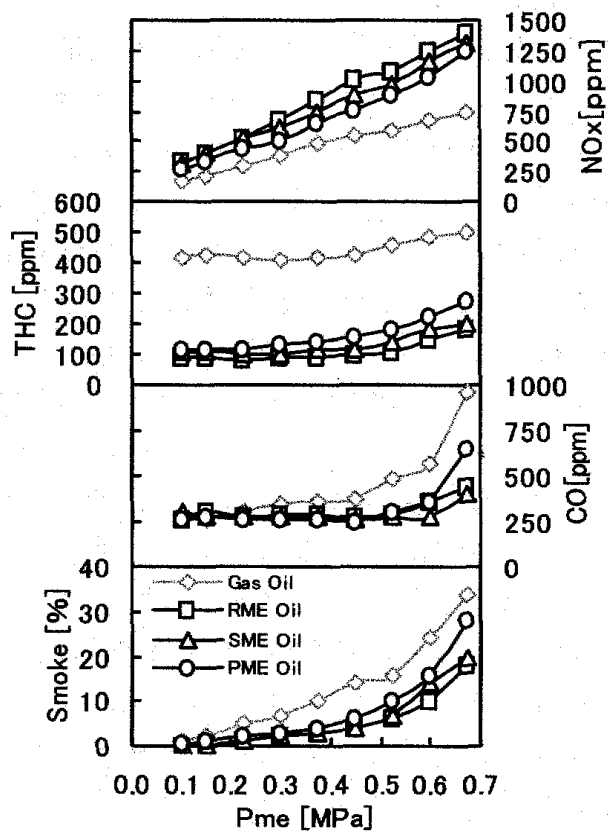

Fig.10 Emission characteristics of biomass fuel
となり寒泠地においても使用可能と考えられる.

（3）オレイン酸メチルのアルデヒド生成量が多く，り ノール酸メチルのアルデヒド生成量は少ない。こ のことからオレイン酸メチルの影響が大きいと 考えられる.

（4）各メチルエステル燃料は, 軽油と比較するとNOx は増加し， THC， CO，排気黒煙濃度は減少する。

（5）飽和脂肪酸割合が少ないとNOXは増加しTHC, 排気 黒煙濃度は減少する傾向がみられる。

\section{考文觔}

(1) Fujiwara, Y.,and Tosaka,S.,Effect of Oxygenated Age nts Addition to Diesel Fuel on formtionProcesses in Particulates and Toxic Substances High environment al tailoring and the mechanism elucidation study su bcommittee of the intermittent combustion in Japanes e (2001) pp.83-88

(2) Yamane,K.,and Kawai,T,and Shimamoto,Y.,Capabilit $\mathrm{y}$ of Biodiesel Fueled Compression Ignition Engines Substances High environmental tailoring and the $m$ echanism elucidation study subcommittee of the inter mittent combustion in Japanese (2001) pp.89-94

(3) Tada,M., and Kitagawa,H.,and Tosaka,S.,and Araki,T., and Okabe, N The Effect of Fuel Properties on Mec hanism of Particulate Matter Japan Society of Mech anical Engineers, A collection of Hokkaido branch office lecture summaries. In Japanese, No.052-1 (20 05) pp.132-133

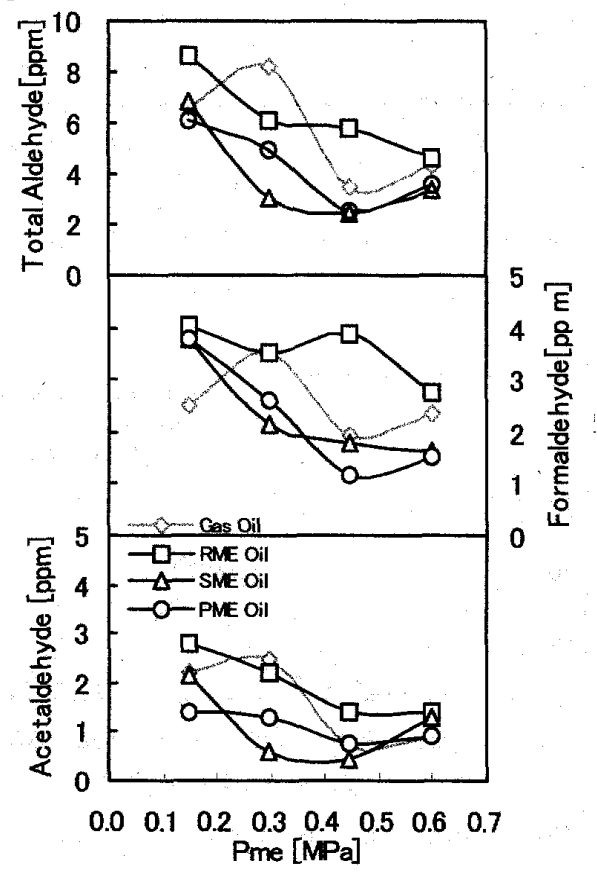

Fig.11 Aldehyde emission trends of biomass fuel 